Southern Methodist University

SMU Scholar

History Faculty Publications

History

$4-2018$

\title{
Global Questions About Rent and the Longue Durée of Urban Power, 1848 to the Present
}

Jo Guldi

jguldi@smu.edu

Follow this and additional works at: https://scholar.smu.edu/hum_sci_history_research

Part of the Social and Behavioral Sciences Commons

\section{Recommended Citation}

Guldi, Jo, "Global Questions About Rent and the Longue Durée of Urban Power, 1848 to the Present" (2018). History Faculty Publications. 13.

https://scholar.smu.edu/hum_sci_history_research/13

This document is brought to you for free and open access by the History at SMU Scholar. It has been accepted for inclusion in History Faculty Publications by an authorized administrator of SMU Scholar. For more information, please visit http://digitalrepository.smu.edu. 


\title{
Global Questions About Rent and the Longue Durée of Urban Power, 1848 to the Present
}

https://doi.org/10.1515/ngs-2018-0012

\begin{abstract}
This article examines the forces, public and private, that have exerted political power over the longue durée of the modern city since 1848 . The article 10 identifies three major turning points that contextualize the modern moment: the rise of democratic movements of 1848 and their gradual targeting of city governments; the rise of an expert-managed, urban reform state beginning in 1870; and the birth of neoliberal state, from 1974 to the present. The article positions the knowledge of urban history within the rise of democratic, participatory move- 15 ments concerned with opening, replicating, and publicly analyzing governmental data.
\end{abstract}

Keywords: Great Britain, British history, cities, urbanization, gentrification, city planning

In or around the mortgage crisis of 2008-10, a new narrative about the affordability of the city began to emerge. Political candidates in both London and New York announced that they would run on a platform targeting high rents. Protestors staged sing-ins in the court in New York to impede the process of 25 eviction. London's squatters and their “open universities” received prominent newspaper coverage. After decades during which other economic issues had appeared more prominent than that of land, the governance of real estate was suddenly at the center of the public imagination, symbolizing the issue of the right to the city by the working poor. Yet these political movements, and the 30 journalism that covered them, left unaddressed the question of the historical conditions in which unaffordable rents or anti-rent protests had emerged. How did rent become unaffordable, and what were the alternatives in terms of city government and market initiatives?

In order to address these themes, this article will address the issue of power 35 over the longue durée of the modern city since 1848, drawing attention to three major turning points that contextualize the modern moment: the rise of

*Corresponding author: Jo Guldi, Southern Methodist University, Dallas, TX 75205, USA,

E-mail: jguldi@mail.smu.edu 
democratic movements of 1848 and their gradual targeting of city governments; 1 the rise of an expert-managed, urban reform state beginning in 1870; and the birth of neoliberal state, from 1974 to the present. This chronology of movements offers to complicate an older narrative about urban power that profiles a general clash between powers from above and from below. At the same time, this 5 overlapping chronology will refine vaguer periodizations that identify the neoliberal merely with the postwar.

In the era since the mortgage and foreclosure crisis of 2008, reality of financial power's influence over housing, access to water, and other forms of infrastructure has become unavoidable. At the same time, however, anti-rent, 10 open-data, and other participatory movements have flooded the scene. A historical narrative of urban power and struggle that highlights a longer conflict between public and private over resources can help us to understand both the historical capture of state power by the market, and how participatory movements have responded or failed to respond to this challenge. The conflicting 15 goals of three historically discrete systems - participatory, expert-managed, and market-driven - still largely structure urban politics, resulting in conflicts over money, power, and access to the city with an uncertain resolution in our own time.

This article aims to advance a new history of urban power by charting these 20 three variables - the rise of participatory politics in the modern era, the creation of urban planning and the movement for the reform of cities through experts and through forces from below, and the rise of the neoliberal city. The perspective taken is one of a longue durée, or at least a moyenne durée of a century and a half, which allows multiple turning points and conflicts to surface, illuminating 25 the space of power between citizen, expert, and market.

The article therefore concludes, not with a final, systemic theory of the modern city, but by suggesting a formulation of how such a story is most likely to emerge sociologically at the present time, in which data and analysis are increasingly the subject of crowdsourced collection and inspection of informa- 30 tion. The article positions the knowledge of urban history within the rise of democratic, participatory movements concerned with opening, replicating, and publicly analyzing governmental data.

Thus the immediate sequel to this article, published as a short article in the same journal number, concludes on a note predicated upon the assertion that a 35 participatory politics of the city has continued to evolve into the information era, and that these new nodes of data citizenship are likely to be some of the major venues collecting, analyzing, and using data about housing, eviction, public space, etc., in coming decades. The historical questions long engaged by urban historians are essential to self-understanding in the sphere of data citizenship. 40 
As a supplement to this article, a speculative call to action for data-driven 1 citizen participation campaigns follows, outlining changes in expenditure over the preceding decades that could better inform a campaign of participatory urban governance.

\section{Power in the Modern City: A Longue-Durée Perspectives and the Need for A New Global Synthesis}

Narratives of "high modernism," "expert power," and the urban planner's oppression of working-class residents describe many of the dynamics between government, peasants, and poor urban residents, not only in North America or Europe, but over much of the modern world for much of the modern era. The 15 narrative of oppression above became seminal with Jane Jacobs' Death and Life of Great American Cities. In the decades that followed, it offered a prototype upon which most histories of architecture, urban planning, and the colonial experience, perhaps most influentially in James C. Scott's formulation of "high modernism" in Seeing Like a State.

Particular moments in our collective past serve to encapsulate this war between state power and the citizen in miniature, and particular episodes of memory have thus become symbolic of the wider conflict. For historians of empire, the immiseration of India's tenant farmers and the racial segregation of New Delhi are both associated with the plans of enlightenment thinkers - the 25 former, with the utilitarian plans for reforming Indian property law drawn up by successive generations of civil servants after the Bengal Settlement of 1793; the latter with the quarantining of white bodies from Asiatic diseases and the threat of terrorism after the Great Rebellion of $1857 .^{1}$

For urban historians, the prototypical narrative of expert power is the Paris 30 of Napoleon III, where city-designed boulevards bisected neighborhoods identified with poverty, crime, and working-class resistance, a project where state alliances with capital served to consolidate wider swathes of geographical property, and the intense replication of architectural and aesthetic forms,

1 Eric Stokes, The English Utilitarians and India (Oxford: Clarendon Press, 1959); Dane Keith Kennedy, The Magic Mountains: Hill Stations and the British Raj (Delhi: Oxford University Press, 1996). 
into the hands of an elite. ${ }^{2}$ In a colonial context, nineteenth-century urban 1 planning has likewise have been shown as the agents of racism and imperial authority, dividing the city into racialized zones and thus perpetuating and extending the conflation of race, caste, and poverty through the built geography of everyday life. ${ }^{3}$

When extended from empire and the domain of Napoleon III, these narratives tend to generate a caricature of the modern period has prevailed that conceptualized power as an arena of struggle between forces above and below, in which power is principally amassed and exerted by the state, especially as it pertains to relationships where the state amasses information and 10 provides technology and citizenship to individuals whose capacities are constructed only in terms of this relationship. From at least the 1970s, twentiethcentury urban planners were routinely caricatured as the face of privilege, ruthlessly exerting power against participatory movements from below, especially with regards to stories of eviction of minorities targeted by slum removal 15 for highway building. ${ }^{4}$ The result of this caricature is a reduction of the politics of the twentieth century to a miniature reinstitution of colonialism, redirected at urban minorities and the working poor.

In America, contemporary historians have revisited the urban planner, contextualizing planners like Robert Moses in the history of booster efforts, and even 20 highlighting the attempt by the state to use state building as a tool to enable participatory governance of housing from below as well as racial integration. ${ }^{5}$ The story of state power has been likewise complicated by recent studies of eviction, for instance that by Matt Desmond, in which market factors - investor opportunity, high market rents, and the absence of public housing figure - rather than the 25 state figure as the major cause of homelessness, debt, and immiseration in poor families. ${ }^{6}$

2 David Harvey, Paris, Capital of Modernity (New York: Routledge, 2003); David P. Jordan, Transforming Paris: The Life and Labors of Baron Haussmann (New York: Free Press, 1995).

3 Stephen Legg, Spaces of Colonialism: Delhi's Urban Governmentalities (Malden, MA: Blackwell Pub., 2007); Manu Goswami, Producing India: From Colonial Economy to National Space, Chicago Studies in Practices of Meaning (Chicago: University of Chicago Press, 2004).

4 The classic work is Robert A. Caro, The Power Broker: Robert Moses and the Fall of New York 35 (New York: Vintage Books, 1974).

5 Peter Eisenstadt, Rochdale Village: Robert Moses, 6,000 Families, and New York City's Great Experiment in Integrated Housing (Ithaca; London: Cornell University Press, 2010); Samuel Zipp, Manhattan Projects: The Rise and Fall of Urban Renewal in Cold War New York (New York; Oxford: Oxford University Press, 2012).

6 Matthew Desmond, Evicted: Poverty and Profit in the American City (New York: Crown, 2016). 40 
Urban history is thus in the process of framing more complicated narrative, 1 one that encompasses narratives of power from many directions - from the state, from investment, and from below. How does the issue of power help us to understand the modern city as the major site of experimentation in participatory governance?

\section{8 and the Birth of Participation}

The participatory movements of the 1960s, which defined themselves against the 10 power of the urban planner, are but one episode in a longer story of democratic demands for the decentralization and responsiveness of centralized control. Consider the Paris of Napoleon III; the urban era that opened in Europe in 1848 was not only an era of crowds and spaces; it was also a moment intensely rich in theories of democratic governance, from the Chartist movement in 15 England to the trade unions of France, the democratic movements of Prussia and Italy, and the rallying cry of the Communist Manifesto. The rise of the city thus coincided with an increasing pressure for participatory civic government, one expressed in Paris and London through demands for increasing accountability of urban infrastructure to ordinary citizens.

Cities like New York and London thus helped to dramatize the class conflict between poor tenants and rapacious landlords that had long played out in the countryside. From the English enclosure crisis, to the "anti-rent" era in upstate New York, rural consolidation of property by elites was linked to urbanization in two major ways: first, it forced families off of the land and opened the possibility 25 for a recognition of class conflict; and secondly, at least by the 1840s, rural land seizures were becoming the subject of documentation by urban working-class newspapers in both countries. ${ }^{7}$ On both sides of the Atlantic, for example, the eviction epidemic in rural Ireland and Scotland was documented for urban readers by newspapers in Edinburgh, New York, and London. ${ }^{8}$ Rural scenes of 30

7 Reeve Huston, Land and Freedom: Rural Society, Popular Protest, and Party Politics in Antebellum New York (New York: Oxford University Press, 2000); Charles W McCurdy, The Anti-Rent Era in New York Law and Politics, 1839-1865, Studies in Legal History (Chapel Hill: University of North Carolina Press, 2001); Thomas Summerhill and James C. Scott, eds., 35 Transatlantic Rebels: Agrarian Radicalism in Comparative Context (East Lansing: Michigan State University Press, 2004).

8 Andrew G. Newby, Ireland, Radicalism, and the Scottish Highlands, C. 1870-1912 (Edinburgh Q3 University Press, 2007); L. Perry Curtis, Depiction of Eviction in Ireland 1845-1910 (Dublin: University College Dublin Press, 2011); Christopher Morash, "Ghosts and Wires: The Telegraph and Irish Space," in Ireland and the New Journalism, eds. Karen Steele, et al. (Basingstoke: 40 
eviction were connected by train and telegraph to the city, and the former gulf 1 separating rural and urban cultures began to break down.

The result of these technological transformations was a watershed in public consciousness of land seizure as a mechanism of class violence. Half a century before, Scottish landlords had burned down the homes of their tenants in the 5 Highland Clearances with little protest from without; but by the 1880s, the battering rams used to turn out rent-resisting tenants in Galway were documented day by day in the newspapers of New York and London. ${ }^{9}$ Populist journalists and politicians such as Henry George and Patrick Ford, editor of the American newspaper The Irish World and American Industrial Liberator, drew parallels 10 between colonial systems of landlord power ("landlordism", in the idiom employed by both writers) and the urban amassing of control of infrastructure, real estate, and rents by the urban elite. ${ }^{10}$

Cities dramatized the way that wealth was created not only by an avantgarde of entrepreneurs, but also by an army of clerks, managers, marketers, 15 salesmen, lawyers, and other workers, who depended upon living near the city for their continued participation in the economy. ${ }^{11}$ To borrow the characters from the journalist Henry Mayhew: the beggar, street performer, and street vendor all found ways of diverting capital into their pockets, based partially on their occupation of busy city centers. Yet these same characters could easily 20 be ejected from access to the city if real estate prices and rental costs were allowed to ceaselessly intensify.

These insights contributed to a program of collective development that turned the old logic of improvement on its head. If improvement, since the seventeenth century, had been defined by economic enrichment pursued by the 25 most learned and capable members of society, then by the nineteenth century, economic thinkers about land were increasingly characterizing the economy as a collective undertaking whose success depended upon the participation of

Palgrave Macmillan, 2014), 21-34; Ely M. Janis, A Greater Ireland: The Land League and Transatlantic Nationalism in Gilded Age America, History of Ireland and the Irish Diaspora (Madison, Wisconsin: The University of Wisconsin Press, 2015).

9 L. Perry Curtis, "The Battering Ram and Irish Evictions, 1887-90," Éire-Ireland 42, no. 335 (December 10, 2007): 207-28, https://doi.org/10.1353/eir.2007.0039. Cf. T. M. Devine, Clearance and Improvement: Land, Power and People in Scotland, 1700-1900 (Edinburgh: John Donald, 2010).

10 Edward T. O'Donnell, Henry George and the Crisis of Inequality: Progress and Poverty in the Gilded Age (Columbia University Press, 2017), 102-17. See also Janis, op. cit. 11 O’Donnell, "Henry George," 81-4. 
renters, tenant farmers, and indigenous peasants. ${ }^{12}$ City and national govern- 1 ments, these writers urged, could be used to create a new commons in terms of infrastructure, where roads, water, and sewers would be, by design, available to all, but subsidized by those most able to pay, with the design of increasing the ability of those at the society's margins to both enjoy and contribute to the 5 collective good.

Populist demands were soon accompanied by structural changes to the regulations of property-ownership in the city that signaled an increase willingness to employ the state to intervene in new spheres. The rent strike, first explored as an organized weapon in Ireland's land war during the 1880s, was 10 gradually imported into the city. ${ }^{13}$ By the first decades of the twentieth century, rent strikes rocked Edinburgh, Britain's East Coast and neighborhoods in New York, resulting in some of the first rent control laws. ${ }^{14}$ Urban planning, for all of its dependence upon elite power structures, often responded to these demands from below, and individuals charged with state functions of land-use planning 15 on behalf of the government began to experiment: with participatory mapping from below, in the British Land Use survey, and with citizen surveying and government response, in the Resettlement Administration and other organs of the New Deal. ${ }^{15}$ A balance between popular pressure and civic response was born of this moment.

12 In the case of the city, the writers are Henry George; in the case of the countryside, the theory develops in the country and matches the outline of the "labor theory of space" described by Andrew Sartori in his work on ideas about the governance of India and Ireland, especially around George Campbell. Andrew Sartori, Liberalism in Empire: An Alternative History (Berkeley: 25 University of California Press, 2014), http://public.eblib.com/choice/publicfullrecord.aspx? $\mathrm{p}=1693158$.

13 For Irish tactics, see Curtis, op. cit.; Michael Davitt, The Fall of Feudalism in Ireland; or, the Story of the Land League Revolution (London: Harper \& Bros., 1904).

14 Michael Lipsky, Protest in City Politics: Rent Strikes, Housing, and the Power of the Poor (Place of publication not identified: Rand McNally, 1970); Michael Lipsky, Rent Strikes: Poor Man's 30 Weapon (Madison: University of Wisconsin, Institute for Research on Poverty, 1969); Dave Burn, Rent Strike, St Pancras 1960 (London: Pluto Press for Architectural Radicals Students Educators, 1972); Robert M. Fogelson, The Great Rent Wars: New York, 1917-1929 (Yale University Press, 2013); “Les Glasgow Rent Strikes De 1915 Ou Quand La Désobéissance Civile Des Femmes Contraint Le Législateur When Female Disobedience Lays down the Law: The 1915 Glasgow Rent Strikes," Revue Lisa 6, no. 4 (2009): 40-56; Paul Taylor, “Homes for Heroes,” in Heroes or 35

Q4 Traitors?: Experiences of Southern Irish Soldiers Returning from the Great War, 1919-39, 2015, Chapter 4.

15 Jess Carr Gilbert, Planning Democracy: Agrarian Intellectuals and the Intended New Deal, 2015, http://ezproxy.uniandes.edu.co:8080/login?url = http://www.jstor.org/stable/10.2307/j. ctt1bh4bp7; Simon Rycroft and Denis Cosgrove, "Mapping the Modern Nation: Dudley Stamp and the Land Utilisation Survey,” History 40, no. 1 (1995): 91-105. 


\section{The Reform State from 1880}

The birth of expert rule in the city has its origins with the eighteenth-century infrastructure state, and the rise of public health administrations to face the cholera outbreaks of the 1830s and 40s. But the reform of city administrations came of age only after the 1880s with an expanding set of reformers whose interests, in part, responded to pressure from below. Directly inspired by earlier generations of reformers - for instance the sanitary reforms of Edwin Chadwick and the movement for allotment gardens - the social reformers of the 1880s could take for granted that reform moved not merely in the world of legislative 10 code but also in the materiality of the modern city. ${ }^{16}$

By the generation of Octavia Hill, the tools of urban reform associated with the rise of London in the 1870s included the state subsidization of infrastructure development, the imposition of rent control, the creation of walking paths and public spaces, and the regulation of noxious contaminants to air and water. ${ }^{17} 15$ Hill's own path to urban reform is symptomatic of a generation: inspired by her maternal grandfather's work in sanitary reform, Hill helped to found the movement for open spaces, protecting Hampstead Heath for public use, before becoming associated with the movement to mediate rent disputes. ${ }^{18}$ In her writings about public space, Hill clearly saw the continuity of the state as key to executing this new commonwealth in the landscape: the powers of eminent domain used for seizing property to create sanitary reforms could be applied, she suggested, to create new common land for the poor. ${ }^{19}$

Hill was also influenced by the work of radical historians and political economists in her own day, who asserted that a collectively-owned peasant 25 commons had preexisted the enclosure acts, 5 million acres in all by one computation. ${ }^{20}$ In her essays about Our Common Land, she urged that the

16 Chadwick. Allotment Gardens.

17 David Stradling and Peter Thorsheim, "The Smoke of Great Cities: British and American Efforts to Control Air Pollution, 1860-1914," Environmental History 4, no. 1 (January 1, 1999): 631, https://doi.org/10.2307/3985326.

18 Nancy Boyd, Josephine Butler, Octavia Hill, Florence Nightingale: Three Victorian Women Who Changed Their World (London: Macmillan, 1984); Elizabeth Baigent et al., "Nobler Imaginings and Mightier Struggles": Octavia Hill, Social Activism and the Remaking of British Society 35 (London: Institute of Historical Research, 2016), http://www.humanities-digital-library.org/ index.php/hdl/catalog/book/octaviahill.

19 Octavia Hill, Our Common Land (London: Macmillan, 1877), 7-8.

20 For instance, Kenelm Edward Digby, An Introduction to the History of the Law of Real Property: With Original Authorities, Clarendon Press Series (Oxford: Clarendon Press, 1875); Joseph Fisher, The History of Landholding in England (London: Longmans, Green, \& co, 1876). 40 
state restitute the forfeited commons of the past, creating a new commons of 1 playgrounds and open spaces for the enjoyment of persons of all classes, especially their children. The benefits of common space must transcend the limits of capital, she urged: "[I]s the privilege of space, and light, and air, and beauty not to be considered for the small shop-keeper, for the hard-working 5 clerk, who will probably never own a square yard of English land, but who cares to take his wife and children into the country for a fortnight in the summer?"21

The complications of class in each of these movements for a public space were complicated by punitive attitudes towards the poor, recirculated by lurid journalistic accounts of the racial difference and barbarism of the destitute, the 10 so-called "residuum" of society, characterized sometimes as both an object of knowledge and a potential threat to civilization. The concept of the "residuum" seeped into the mindset of the ladies of the settlement houses and Charity Organization Society, even as they publicized rent as a source of differential access to economic stability. ${ }^{22}$ Similarly, fear of the "residuum" induced a 15 mapping of disease, poverty, and crime as coterminous problems, to which eugenics was proposed as a problem, although others urged that all of which could plausibly be solved by the transformation of the built environment, including better housing, less crowded neighborhoods, access to parks and public spaces, sanitation, and access to clean drinking water. ${ }^{23}$ In the context 20 of American history, Progressive-era urban reforms such as street trees, public parks, slum reform, the "city beautiful" movement, and public schools have been tied by scholars to the punitive attitude of gilded age elites, whose visions of urban beauty did not necessarily include the democratic management of the city by a diverse and expanding city population. ${ }^{24}$

While concepts such as the "residuum" encouraged a distance between many progressive-era elites and their would-be subjects, the desire for reform

21 Ibid., 7.

22 Ross McKibbin, “Class and Poverty in Edwardian London,” in The Ideologies of Class: Social 30 Relations in Britain, 1880-1950 (Oxford [England]: Clarendon Press, 1990); Jose Harris, "Between Civic Virtue and Social Darwinism: The Concept of the Residuum," in Retrieved Riches: Social Investigation in Britain, 1840-1914, eds. David Englander and Rosemary O'Day (Aldershot, Hants, England: Scolar Press, 1995), 65-89.

23 Peter Thorsheim, Inventing Pollution Coal, Smoke, and Culture in Britain Since 1800 (Athens, Ohio: Ohio University Press, 2006), http://site.ebrary.com/id/10156428; B. Luckin, "Revisiting 35 the Idea of Degeneration in Urban Britain, 1830-1900,” Urban History 33, no. 2 (2006): 234-52. 24 Roy Lubove, The Progressives and the Slums: Tenement House Reform in New York City, 1890-1917 (Pittsburgh: University of Pittsburgh Press, 1962); Roy Rosenzweig, "Middle-Class Parks and Working-Class Play: The Struggle Over Recreational Space in Worcester, Massachusetts, 1870-1910," Radical History Review 1979, 21 (October 1979): 31-46, https://doi. org/10.1215/01636545-1979-21-31. 
and encounter with the other also changed the minds of some elites about what 1 exactly their charge was. Recent accounts of encounters of the progressive elites who "slummed" as workers in settlement houses in both America and Britain have insisted on the capacity of these cross-class encounters to transform the mindsets of both parties. ${ }^{25}$ Thus era of urban planning was also, in many ways, 5 an era when many began to dream about what a city governed by urban participation would look like.

In Britain, at least, the shift to urban reform coincided with the broadening right to vote among working-class men in 1867 and 1884, as well as wide popular movements that elected some of the first working-class individuals to 10 public office on the urban and national scale. Fabian visions of the city with drinking water for all were inextricably bound up with the possibility of an electorate naming their own representatives. In America, the 1880s saw a surge of working-class activism around the eight-hour working day, the trade unions, and New York's United Labor Party, with the active use of public spaces for 15 protest by democratic workers' movements. ${ }^{26}$

Following the vision of nineteenth-century improvers who insisted on infrastructure as a way of forcing capital to flow horizontally, twentieth-century urban planners would use tax revenue to develop parts of the city that were left behind in terms of access to infrastructure. In the transatlantic exchanges of 20 the nineteenth century, popular writers from the Chartists to Henry George urged that legislation and taxation of land could form a weapon in the hands of the poor to break the power of landlords to charge high rents for slums. These writers narrowed Marx's assessment of the bourgeois acquisition of all wealth to explain how, in modern cities, infrastructure such as roads, water, and sewers 25 was monopolized by corporations and the state.

Their analysis explained what we would now call the "gentrification" of peasants from the countryside and working-class citizens from the city: challenges to the survival of community associated with continued occupation, predominantly faced by poorer and working-class families and associated with 30 the movement upwards of rents and property prices in an expanding economy. Against this background, progressive-era calls for rent control abounded in the form of pleas for government-sponsored resettlement, rent control, housing for

25 Chad C. Heap, Slumming: Sexual and Racial Encounters in American Nightlife, 1885-1940, Historical Studies of Urban America (Chicago: The University of Chicago Press, 2009), https:// login.revproxy.brown.edu/login?url = http://search.ebscohost.com/login.aspx? direct $=$ true\&scope $=$ site\&db $=$ e000xna\&AN $=281560$.

26 Edward T. O’Donnell, Henry George and the Crisis of Inequality (New York: Columbia University Press, 2015), xx-xxvi. 
the working classes, allotment gardens for working men, and provision of 1 infrastructure such as drinking water to all neighborhoods. Both urban and rural in its implied remedies, land reform encompassed a wide swath of demands that would ameliorate income inequality and better the access to cities and markets by members of the working poor, whether they dwelled in urban 5 tenements or rural hovels.

Rent controls and land reform also offered a specific remedy for income inequality and differential access to the city, more modest than Marx's dictatorship of the proletariat, or even the unionization of factories, in the form of policies that targeted the hoarding of land in particular. In this vein of land- 10 based ideology, land played a key role, unlike factories, capital, or other investments, in limiting the potential of any citizen to enjoy modern life. According to Henry George, who was among the most prominent and popular thinkers in the transatlantic nexus of progressive-era urbanism, the rich had monopolized the central areas of town with mansions, clubhouses, and board- 15 rooms, which took up valuable access to community-provided infrastructure such as sewers, train stations, and street lights that would otherwise be used by efficient, small dwellings split up among multiple working families. Consolidation of urban land by the elite, in other words, actively siphoned resources away from poorer families, who by contrast were crowded in dirty, 20 unlit tenements in crowding conditions hitherto unprecedented in human history. ${ }^{27}$ In the idiom of reformers, landlord consolidation of resources was linked directly to public health crises among the poor.

By the end of the nineteenth century, urban designers and theorists such as Patrick Geddes were using the category of urban planning to rethink the cause of 25 housing reform, motivated by experiences of cross-class solidarity in the settlement house, for instance Geddes' experience of living in the midst of Edinburgh slums and founding a settlement house there whilst teaching biology at the University of Edinburgh. ${ }^{28}$ In this pursuit, Geddes was clearly inspired by the example of earlier settlement houses like Toynbee Hall, the famous manor-like 30 plantation of Cambridge and Oxford students in the midst of the London slum, designed to uplift the working poor through the memory of folk dances and other communal activities, undertaken within the gothic surroundings

27 For George's critique of Fifth Avenue against the crowded conditions of Manhattan only blocks away, see O’Donnell, 73-80.

28 Marshall Stalley, Patrick Geddes: Spokesman for Man and the Environment (New Brunswick, NJ: Rutgers University Press, 1972), 17-22. 
bespeaking the importance of patronage from a literary and Christian elite. ${ }^{29} 1$ Where Toynbee Hall and its activities partook of elitist meditations on eugenics and the residuum, however, Geddes's settlement house and later urban planning practice were informed by a new politics. Inspired by the pattern of Octavia Hill's ideas about common land, continental ideas about anarchist politics via 5 Élisée Reclus and Peter Kropotkin, and Geddes's own studies in evolutionary biology applied to history. Thus Geddes' settlement house was designed to implement evolution by exposing students to the reality of their "environment" in the form of the slum.

In Geddes's later writings on urban planning, the theme of the collectively- 10 owned environment returned again. He urged the planners to build parks, playgrounds, museums and culture institutes as meeting grounds for the classes, becoming the "Cathedral of the People." "These larger human and social uses must dominate our constructive tasks," he wrote. ${ }^{30}$ Eschewing the slum-clearance projects that were already appearing in contemporary London, 15 Geddes urged the government instead to concentrate on buying one lot for sale at a time, stippling neighborhoods with small parks and playgrounds throughout.

In the era of land reform, urban planning was put to the cause of socialist promises of extending the promise of landownership to all. These demands on 20 the state to extend its work took the form of a land-use survey of Great Britain designed to extend state control over the nation's land as a whole. For the Fabian socialists in Britain, key to this vein of thought was a new set of policies aimed at diminishing income inequality through the administration of infrastructure and property taxes. A uniquely socialist view of rent emerged, based in 25 the rejection of Marxist economics and the privileging of rent control, housing, infrastructure, and urban spaces as the mechanism for insuring relatively equal access to Britain's wealth. As Mark Bevir explains, "In their view, this theory of rent blurred the distinction between classes, making it possible, first, to equate socialism not with ending capitalism but with taxation of unearned increment 30 for the benefit of society and, second, to reject a revolutionary politics in favor of parliamentary gradualism and the permeation of bourgeois parties."31 Rent politics, in short, provided a means to build upon the solidarities proposed by reformers like Octavia Hill, which would insure that the working class partook of

29 Deborah Weiner, “'The Best for the Lowest': The Settlement Movement," in Architecture and Social Reform in Late-Victorian London (Manchester: Manchester University Press, 1994).

30 In Stalley, op. cit., 51.

31 Mark Bevir, "Theories of Rent," in The Making of British Socialism (Princeton, NJ: Princeton 
Britain's growing wealth, so long as the state agreed to regulate the urban 1 landscape.

Thus state regulation became the new orthodoxy of the state, embraced in both conservative and radical varieties, and implemented in the form of new property taxes that paid for state-built housing, allotment gardens for the poor, 5 parks and playgrounds, swimming pools and schools across the nation. ${ }^{32}$ Socialists such as Sidney Webb and land reformers such as Jesse Collins imagined that taxes on land could force the rich, in higher-taxed neighborhoods, to pay the majority of town costs, while government programs could simply assign a portion of underdeveloped land to be farmed as allotment gardens by working- 10 class families. ${ }^{33}$ Access to cheap land would simultaneously cushion workingclass families from the threat of starvation due to falling wages, and keep them close enough to the city center to allow initiative to swell into entrepreneurship without the threat of ejection due to rising rents.

In the meantime, infrastructure subsidized by property taxes would allow 15 families to get to work, and allow the state to improve the conditions of all of its citizens. Wise managers would apply these high taxes to careful coordination of infrastructure (like train lines), sewers, and frequent investments in new housing for the poor. In this way, the poor would no longer be squeezed into the worstconnected corners of town, nor would the housing stock occupied by the poor be 20 allowed to disintegrate, any more than any part of a national highway system was allowed to disintegrate. ${ }^{34}$

By the end of the Second World War, the vision of the redistributive state and its role in the city was being actively implemented in Great Britain. The Uthwatt Committee version of land planning was, in terms of finance, an 25 enormous step in the direction of communal financing of collective geographic improvements. Government subsidies could boost the ability of poorer areas to pay for roads, parks, schools, and other improvements. The government would be the broker of land improvements, and communal taxes would fund the development of infrastructure and improved housing stock. In the land-planning 30 scheme of the Uthwatt Committee, $75 \%$ of development costs would be paid for

32 David Matless, Landscape and Englishness (London: Reaktion Books, 1998).

33 John Broich, London Water and the Making of the Modern City (Pittsburgh, PA: University of Pittsburgh Press, 2013), http://site.ebrary.com/id/10853003; Paul Readman, Land and Nation in 35 England: Patriotism, National Identity, and the Politics of Land, 1880-1914 (Woodbridge, UK: Boydell Press, 2008).

34 Albro Barker, Henry George (New York: Oxford University Press, 1955); Bernard Newton, "The Impact of Henry George on British Economists, III," American Journal of Economics and Sociology 31, no. 1 (January 1972): 87-102, doi:10.1111/j.1536-7150.1972.tb03144.x; Geoffrey Lee, The People's Budget: An Edwardian Tragedy (London: Henry George Foundation, 1996). 
by those whose land was improved. The remaining $25 \%$ of costs would be 1 subsidized by the government and ultimately born by tax-payers. ${ }^{35}$

This, in short, was the consensus about urban planning and state-controlled rent that dominated not only Britain but most other developed nations by the beginning of the twentieth century. For the majority of the twentieth century, it 5 insured that citizens of any class could generally look for a better standard of living, greater access to health, and even more diverse access to education and jobs, than had their parents, simply by right of inhabitation of an increasingly cleaner and tighter city overseen by urban planning more generally in all of its regulatory guises: health inspectors, building codes, the planting of public 10 schools, the improvement of urban train and bus lines, and the creation of rent control.

By the 1960s, land nationalization remained an integral part of the Labour Party platform, which regularly raised the possibility that government take an ever-more extensive role in terms of its geographic reach and its mandate for 15 building for the common good. The promise of lower rents and better housing for all secured Labour much of its margin in elections. As faith broke in the state's abilities to administer land and housing, many foretold that the collapse of the welfare state would not be far behind. Land nationalization had appeared as the balm to salve a decade during which prices of land and rent had tripled 20 while wages stagnated. As Time magazine explained, "land has become a highly emotional issue in Britain," at a time when the increase in prices had driven "the cost of a decent home beyond the reach of countless thousands of British families." 36 Land nationalization was the last and most viable platform offered by the Labour Party among its nationalization schemes. Amongst its assurances, 25 Land reform promised additional housing, something enticing to the average voter, and little promised by the nationalization of coal and other industries that so far had failed to produce jobs. According to editorialists like Bernard Levin of the Times, upon the success or failure of Wilson's Land Nationalization gambit rested the fate of socialist nationalization as a whole. ${ }^{37}$ Why was so much hope 30 and fear entangled in the prospects of Wilson's ability to govern? In the era of squatters, the claims of government experts to rationally resolve the pressures of the housing market had been put to the test, and in the eyes of many, the state had failed.

The balance between popular, democratic movements and the state lasted at 35 least until the rise of neoliberal government challenged popular governance

35 "State Control of Land Development," The Glasgow Herald (September 10, 1942): 4.

36 “A 'Silly Little Diversion,”, Time, 103, no. 16 (April 22, 1974): 44.

37 B. Levin, “Up with this the voters will not put,” The Times (October 4, 1973): 22. 
from below, beginning in the 1970s, with a new political agenda that challenged 1 government bureaucracy with a new vision of market efficiency drawn from the writings of Friedrich Hayek and others. To these writers, government regulations of rent prices were anathema and the protection of the investor was sacrosanct. By the mid-1970s, national policies in both London and New York were liberal- 5 izing controls over banks, making available immense sums of money for real estate investment, with the result of buoying the prices of land and rent in both cities. Greater sums of money were controlled by private developers in an age of Donald Trump and similar real estate fortunes; it was their will, rather than the exercise of a Georges-Eugène Haussmann or Robert Moses, that determined the 10 availability of affordable housing, the access of ordinary people to existing infrastructure, and even the availability of tax income for parks, schools, sewers, and other municipal improvements. Participatory reformers who targeted urban planners were chasing a smaller and smaller target, as the real power was increasingly held elsewhere.

\section{Neoliberal City Policy Is Born}

The drama that is emerging from recent studies in finance is one of a rebellion of 20 financial elites. Intellectual historian Daniel Rodgers characterizes its roots in a utopian infatuation with the freedom of information across economic departments and law schools in the 1950s and 60s. But for both Rodgers and David Harvey, neoliberalism entered policy as a putative solution to the stagnating incomes and rising inflation of the 1970s, albeit one that allowed an elite 25 rebellion against regimes that depended upon taxation as the basis for social programs, for instance, the reform state of urban planning. ${ }^{38}$ Both ideological and technical in nature, financialization and neoliberalism combined to remove many of the choices about the development of cities and housing from the hands of urban planners, replacing the experts of the state with a separate caste of 30 bank-appointed experts whose main charge was creating high returns for investors.

In Britain, the political and economic victory over land nationalization had three visible public episodes: first, the Milhench Scandal, in which Labour Prime

38 David Harvey, A Brief History of Neoliberalism (Oxford: Oxford University Press, 2005); Daniel T. Rodgers, Age of Fracture (Cambridge, MA; London: Belknap Press of Harvard University Press, 2012), 41-76. For more technocratic explanations about the changes in banking during this era, see Greta R. Krippner, Capitalizing on Crisis: The Political Origins of the Rise

of Finance (Cambridge, MA: Harvard University Press, 2011). 
Minister Harold Wilson lost his credibility as an exponent of land use planning 1 after private connections between Wilson's secretary and real estate speculators were revealed. Second, the regular appearance of research - much of it collected by the participatory organ Mass Observation - attacking the philosophical underpinnings of land nationalization from a free market perspective; and 5 third, decisions by investors, banks, and the UK Treasury to undergird a major transfer of financial wealth into private real estate, the first episode of what would become a series of policy movements liberalizing and marketizing real estate, that culminated in Thatcher's privatization of public housing for the middle class.

By the 1960s, neoliberal interests in Britain were being given direction and shape by the work of Ralph Harris and Arthur Seldon at the Institute of Economic Affairs, a British think-tank founded upon free market principles and the inspiration of Friedrich Hayek. In 1963 and 1965, the IEA published its first reports on how market principles could reform the state, targeting ineffi- 15 ciencies in the provision of welfare. ${ }^{39}$ But by 1966, their attention had turned towards housing, and a research campaign began to attack state interventions of all kinds. By the mid-1970s, the IEA would harness its research to launch an allout attack on state restrictions on investments in property, rent controls, and indeed, all public ownership of land.

Left out of the vision of land nationalization, however, were the interests of private developers, private investors in real estate, and the construction industry. The institute began to write and circulate pamphlets decrying rent reform, urban planning, and the oppressive delays associated with land nationalization. In 1966 the Institute of Economic Affairs began a research study on Council 25 Housing and House Building, directed by Ralph Harris and funded by major corporations in the construction and real estate sector.

The archive of the Institute of Economic Affairs tells the story of the economic sectors that had the most to lose in a regime of land-use planning strictly controlled by the state. In meetings with construction firms and real estate 30 investors, corporate leaders whose profits had putatively been held up by government bureaucracy were surveyed by the IEA. The result was a laundrylist of corporate complaints about the inefficiency and delay associated with state-led building in the city. ${ }^{40}$

39 Ralph Harris, Arthur Seldon, and Mass-Observation, Choice in Welfare: Reports on Knowledge and Preference in Education, Health Services and Pensions (London: I. E.A., 1971). 40 Hamish Gray, Local Authority Housing: Draft notes on meetings with Wates Ltd (London: Institute of Economic Affairs, April 28, 1966) in "Research Projects File: Choice in Housing, 1966 Jan-June,” n.d., Institute of Economic Affairs, GB, 246.4, Hoover Institution Archives. 
Conversations with corporate leaders raised real issues about the efficiency 1 of the state in the urban planning regime of socialist nations. From the private point of view, the entire land use bureaucracy and urban planning enterprise represented a choke on profits, by delaying any proposed building scheme for years - sometimes for a decade - while the proposal was inspected and revised 5 for its fit with urban planning. By the end of the 1960s, Britain was in the midst of a housing and unemployment crisis. While recruiting corporations to their cause, the Institute urged that the "discussion on housing is dominated by political and social considerations leading to uncritical demand for more public intervention which increases the role of local authorities and restricts the build- 10 ing industry from employing its full potential to meet the increasing housing shortage." 41 By mirroring private frustrations with the public sector back to corporations, the IEA was able to recruit funding and foment an organized attack on state plans of land use.

In conversations with the IEA, representatives of private companies like 15 Wates voiced their belief that they could provide housing more cheaply without the costs imposed by government delays, and that in the midst of building housing, they could also help to solve unemployment. ${ }^{42}$ Local authorities, they urged, used land inefficiently. For instance, urban green belts contributed to the high prices of land "by artificially increasing the scarcity of land and by forcing 20 high density (i. e. high rise and high cost) building on internal authorities and private developers." ${ }^{43}$ Public housing was another target of potential wastefulness on the government's behalf. "At Sutton the housing committee insisted that a tower block should be built with no central heating installation on the grounds that tenants should be free to choose their own," they explained. "But individual 25 provision is vastly more wasteful and expensive."44

Yet the complaints voiced by the private builders in this archive hardly amount to a resounding indictment of an inept and wasteful bureaucracy. Rather, the lobbyists of the Institute of Economic Affairs were recording every possible argument that might help them to attack a Labour platform of land use. 30

41 G. E. Blundell, letter to W. Burns, October 18, 1966, "Research Projects File: Choice in Housing, General,” n.d., Institute of Economic Affairs, GB, 246.1, Hoover Institution Archives. It was funded by Messrs. Wates, John Laing, John McLean, and E. R. Beecher, all construction firms. See also letter G.E. Blundell to A.C. Bryant, October 28, 1966; letter to E.R. Beecher 35 October 4, 1966, ibid.

42 Hamish Gray, Local Authority Housing: Draft notes on meetings with Wates Ltd (London: Institute of Economic Affairs, April 28, 1966) in "Research Projects File: Choice in Housing, 1966 Jan-June,” n.d., Institute of Economic Affairs, GB, 246.4, Hoover Institution Archives, 7-8.

43 Ibid., 53.

44 Ibid., 16. 
Builders in the construction trades could easily describe a long list of projects that 1 might have run differently had they been in charge. The green belt was not left underdeveloped by incompetent bureaucrats out of a failure to calculate the possible revenue; rather its history dated back to nineteenth-century ideas in public health about the circulation of air in the city, and later movements, from 5 the time of Octavia Hill, urging that the children of poor families have access to play spaces. Similarly, individual heating units, however, had likely been left to the consumer to install, not out of the failure to estimate general costs, but out of a concern for inclusivity. Unfurnished apartments might make the Sutton tower affordable by residents who otherwise would not have been able to live there.

The Institute was not set up to weigh the costs and benefits of state and market activity for the common good, however; it was, rather, a war-room for drawing up plans with which to attack state bureaucracy and private taxation. Through their conversations with building firms, they gathered early arguments about employment. In 1966-7, they carried out a survey of residents of public 15 housing that supplied them with data about their experiences. ${ }^{45}$

For academic advisors, the IEA recruited lecturers, readers, and professors of town planning, urban studies, land economy, finance, economics, and valuation, including JB Cullingworth, author of a textbook on town and country planning, and Ralph Turvey, author of a study of the price analysis of electricity. 20 They promised that they would right the unimpressive outcome of this plethora of good intentions," characterized by "a new housing or rent act on average once every three years." ${ }^{46}$ Their approach would contribute economic rigor that has "rarely been borough to bear in Britain where most recent work" was "more or less unreliable." 47 Internally they complained that "no housing research in 25 Britain since the end of the last war has been conducted along these microeconomic lines." Preliminary polling suggested that $60 \%$ of heads of households opposed rent and price controls. They could see a "substantial frustrated demand for owner-occupation."48

45 "Research Projects File: Choice in Housing, 1966 Jan-June," n.d., Institute of Economic Affairs, GB, 246.4, Hoover Institution Archives; "Research Projects File: Choice in Housing, 1966 Oct-Dec," n.d., Institute of Economic Affairs, GB, 246.5, Hoover Institution Archives; "Research Projects File: Choice in Housing, 1967 Jan-Mar,” n.d., Institute of Economic Affairs, GB, 246.6, Hoover Institution Archives.

46 "IEA Inquiry into the Market for Homes" in "Research Projects File: Choice in Housing, General,” n.d., Institute of Economic Affairs, GB, 246.1, Hoover Institution Archives.

47 Ibid.

48 "Confidential: IEA Housing Research Programme, 'A Market for Homes;" in "Research Projects File: Choice in Housing, General," n.d., Institute of Economic Affairs, GB, 246.1, Hoover Institution Archives. 
In 1973, Martin Pawley published The Private Future, where he documented 1 the privatization of many activities once considered public. It was denounced by liberal commentators, but their anger at the text did little to address an already pervasive - and still spreading - culture of privacy. The roots of the new suspicion of land nationalization culture can be located somewhere between 5 the 1860s Victorian cult of the domestic sphere, with its consumption of wallpaper and furnishings and its focus on individual taste as the highest form of expression, and the emergence of the middlebrow, the domestic aesthetic of cheap paperback mystery novels and suspicion of outsiders that arose in the 1930s. Pawley's ideas have also been linked to the re-importation of southern 10 agrarians, with their encomia of government devolution and the family farm, which had been influenced by English Catholics like Hilaire Belloc from the 1920s. By the 1950s, these were blending into a new intellectual cult of the free market. Beginning around 1960, the Institute of Economic Affairs began to gather economists critical of government policy in Britain, putting together 15 case studies on the failures of nationalization schemes, lists of restrictive practices in Britain and evidence as to how they stifled economic growth. The institute joined an international movement that questioned government influence in the private sphere, inviting free-market advocates like Milton Friedman to speak and publish. In 1974, Alan Walters, the future personal economic 20 advisor of Margaret Thatcher, began authoring economic essays that envisioned a world in which the sewers and roads themselves, as well as all housing and public space, had been privatized. ${ }^{49}$

Walters and other LSE faculty affiliated with the IEA began to issue pamphlets that decried government interference with the property market and a return 25 to laissez-faire, private ownership of land as the sole method for justly adjudicating the wars between squatters and council residents, between the deserving and undeserving poor. One such pamphlet, "Government and the Land," struck straight at the institutions by which modern governments had, for nearly a century, regulated city development: "Is town planning necessary?" they 30 asked. $^{50}$ Through the influence of these pamphlets, the message spread. Editorials in the London Times began to allude with praise to urban planning

49 J. B Heath, Not Enough Competition? Business Restrictive Practices Examined (London, 1961); A. Vice, Balance-sheet for Take-overs (London 1961); B.S. Yamey, Resale Price Maintenance and Shoppers' Choice (London 1960).

50 A. A. Walters, Government and the Land Does State Control Help or Hinder?: Is Town Planning Necessary? Does Land Speculation Intensify Inflation? Is Nationalisation the Cure? 
experiments that did away with zoning and other forms of government control, 1 pointing to the model of Houston, Texas. ${ }^{51}$

These coordinated publications were strategic opportunism on the part of the right. Walters deployed a body of thought that had slowly collected since 1966 about the limitations of council housing, town planning, and public infra- 5 structure. These treatises looked backwards nostalgically to a day when private railroads covered Britain, and pointed across the ocean to bustling, unregulated Hong Kong and its relative creativity faced with economic decline. ${ }^{52}$ The acceleration of proposals for privatization after 1974 marks the date as a good watershed for the decay of a public culture of land.

And so philosophy came to the rescue of politicians who made friends with the reality around them. Front-men claimed to be coining a new school of capitalism, a brave reversal of Keynesianism, built upon moral fiber and selfhelp and a return to Victorian values. That was again but hand-waving. All that was happening was that the politicians were bowing out of the scene. Big words 15 allowed them to pit working-class whites against working-class ethnic populations and play brave heroes. Quipped Plender, "Deregulation is also one of the few radical courses of action open to politicians that appears to carry little shortterm political or budgetary cost."53 But the radical ideas at work in 1982 belonged to the bankers, not to the politicians.

Designed to solve the exclusions characteristic of the age of empire, the era of neoliberal landlordism merely reduplicated them. The war of the stock-exchanges, where London and New York competed for the fewest regulations, benefitted only those interests who could afford to compete in such a context. That meant not only large corporations and large investors, but also large nations. The pound 25 sterling and dollar remained high even while the Peso was devalued.

\section{The Landlord's City}

Landlordism is the political economy of exclusion. The problem with it is not that it is short-sighted or anti-growth; it is sometimes both or neither of those

51 'Institute Points to Snags in Land Nationalization,' The Times, February 25, 1974. 1968); D. J. Reynolds and Institute of Economic Affairs, Economics, Town Planning and Traffic 
things. The problem is that it cuts people out of participation in both capitalism 1 and democracy.

The result of this strange new world was a system in which the savings of the rich were being invested not in new industries and infrastructure or factories, but rather in real estate. The sudden arrival of so many willing buyers of 5 pieces of land did one thing: it raised the price of territory to a point where no one could afford to inhabit the land. Land prices were spiraling so quickly that most property-owners in London could get more from interest from reselling the property to another buyer in a Ponzi-scheme-like pyramid than from seeking renters. The consequence was a hollow city; office-buildings stood empty for 10 years, while the nominal buying price and asking rent of the land soared high above what any local renter could possibly afford. Rent had become a tool for squeezing gold out of nothing. It was, as Margaret Reid observed, "the new alchemy." 54 Even before Margaret Thatcher had even taken office, the rising price of land was already turning London into a ghost town.

That, at any rate, was the verdict of Simon Jenkins of the Evening Review, who recycled complaints of a "chronic shortage of clerical labour" in London, the result of house building grinding to a halt, while rents skyrocketed, and investors nonetheless continued to fund office development. ${ }^{55}$

This problem of empty storefronts wasn't resolved until almost a decade 20 later, when retail stores were recruited to pay the rents of high streets. The pattern was unlocked by a geographer, who on his travels around London was struck by the pattern of closing factories and enormous, glamorous retail stores in close conjunction. How to explain this simultaneous dearth and wealth? The traveler in question, Alan Hallsworth, thought he was looking at money being 25 poured into real-estate for the mere sake of the glamour of owning property - a mythic fetishization of property-in-land typical of the era of enclosure. This was the landscape of the real-estate market in action. London's rich bankers owned property and linked their fortunes to a place - to High Street, to Kensington, to Oxford, to the Docklands. For that reason alone did their capital not flee on the 30 international market to Korea or Japan or wherever capital could build new factories and secure a higher rate of interest.

The same thing was happening all across Britain. All over the island nation, land prices were going up so high that the government could no longer afford to act as the developer of public housing, nature trusts, and infrastructure. Thus no 35

54 Margaret Reid, The Secondary Banking Crisis, 1973-75: Its Causes and Course (London: Macmillan, 1982), 63.

55 Simon Jenkins, Landlords to London: The Story of a Capital and Its Growth (London: Constable, 1975), 237. 
new plans for those aims could be taken seriously. Indeed, this offers a new 1 perspective on neoliberalism, characterized not so much as utopian fallacy or as elite red herring: neoliberalism was also about continuing to retain the privilege of one's currency in an increasingly global, and interconnected world. States in Europe and North America, faced with very real competition from the active 5 centers of industry abroad, could no longer afford to prioritize inequality and citizenship by providing public housing. The new focus of the state was on the collective prioritization of currency on a global market, not with the equalization of incomes within the nation. High real estate prices became a strategy, both in 1980 and in 2008, for keeping capital anchored geographically and nationally to 10 places like London and New York.

The point here is that 1974, and a banking revolution, rather than the mere swaying of public opinion, tipped the watershed into neoliberalism. The neoliberal revolution was a bulwark against capital flight. At the same time, it constituted nothing less than a reversal of almost two centuries of political 15 policy. The city of Manchester's municipal government holdings in land had grown every year from 1815 to 1972, through successive eras of highway administration, water authorities, slum clearance and housing development. But by 1972, the standing plans had been completed, and financial and political crises led to reversals of holdings in land for the first time. In a 1988 study of these 20 trends, the urban planners mapping them gasped at what their data revealed, concluding: "The effects of these changes will take some time to work their way through the system but, almost certainly, the 1980s will turn out to be one of the most profound periods of transformation in the sphere of public landownership." 56

\section{Analysis}

The case study here is British - but it may have broader implications. Greta 30 Krippner's analysis of the rise of "financialization" in the United States during the 1970s and 80s, revolves around the repackaging of real estate, local infrastructure bonds, and currencies into new abstract commodities competing for transnational investors. ${ }^{57}$ Theorists of geography, notably David Harvey and Doreen Massey, have drawn attention to geographies of investment around the 35 world since the 1970s as a pattern of accumulation by dispossession, where

56 P. T. Kivell and I. McKay, "Public Ownership of Urban Land," Transactions of the Institute of British Geographers, New Series, 13, no. 2 (January 1, 1988): 177. 
monster profits appear only in geographies structurally devalued by the collapse 1 of currency, real estate prices, or infrastructure. ${ }^{58}$

The larger pattern of a social era when financial investment chases real estate, and real estate investment as a means of the consolidation of a class, fits with more basic theories typical of an earlier generation. At the end of the 5 nineteenth century, radical journalist Henry George had theorized that increases in the bare rental value of property (as opposed to property development) represented sums of money that were forcibly not being invested in factories or roads. The monies went only to further empower the landlords to bid up the price of land against each other, creating a class of people with disproportionate 10 control over where government subsides go and who benefits from them. So long as the price of land kept escalating, and landlords kept bidding it up, that capital remained uninvested in factories or leisure, and workers in turn had less to spend on survival. This system tends to structurally impoverish rent-paying members of the working class who have the fewest investments in real estate. 15 Starting in 1968 and escalating after 1982 capital went through a transatlantic migration from industrial, infrastructure and development investments into inflated real estate values.

The penny-savings-banks and joint-stock-companies of the nineteenth century had been founded upon the belief that capitalism, if it worked as a system, 20 should necessarily enrich the savings of the smallholder or worker whose efforts had contributed to the larger wealth. These efforts devalued their holdings, just as much as they devalued the currency of Mexico. From 1986, Plender of the Financial Times could see over the horizon of time the moment when small investors would rally again, demanding their share of a capitalism that worked 25 for the people: "And while there are no important interest groups opposed to deregulation at present," he concluded his article, "there may well be a political constituency for re-regulation if small investors are hurt in the collapse of securities firms." 59

The 1974 crisis inaugurated an era of the transfer of assets from investments 30 to real estate, resulting in skyrocketing prices for offices and houses within London. So high were these prices that no one could afford to live in London any longer. Families vacated the City en masse, fleeing to cheaper properties outside the city's margins.

58 Doreen B. Massey, Spatial Divisions of Labor: Social Structures and the Geography of Production (New York: Methuen, 1984); David Harvey, Spaces of Capital: Towards a Critical Geography (Edinburgh: Edinburgh University Press, 2001).

59 Plender, op. cit., 48. 
These patterns of migration created extreme exclusion along racial lines, 1 especially after conservative England jettisoned the children of its colored subjects from further protection with the Nationality Act. The occupation that followed that act of exclusion - the 1982 Brixton Riots - had little of the deliberate planning and gentle persuasion characteristic of university occupa- 5 tions by well-educated students. The Brixton Riots were the outburst of the longexcluded, a symptom of rage against injustice pure and simple. Ejectment from the city was especially hard-hitting for the working class and people of color. The various issues were enshrined within The Specials' 1981 ska hit, “Ghost Town." The song is about how the climate of declining economic opportunity 10 and racially-targeted police violence results in boarded up storefronts, a mass exodus from the city, extreme policing of public space and the decline of public musical culture. "Ghost Town" is a song about what it felt like to be poor during the financial crisis of 1974, when jobs disappeared and rents went up, and public rage - failing to identify responsible parties - instead availed itself 15 upon racial minorities.

In the 1950s, squatters had occupied the most derelict parts of London and New York, the places where no one else would live, forming a settler frontier before the urban planner's wrecking ball. But in the 1970s, squatters were to be found in stable neighborhoods and commercial districts. Settlements in London, 20 Amsterdam, Copenhagen, Turin, Paris, Madrid, and Stockholm were along the waterfront and inner city, the areas already targeted in urban planning schemes for redevelopment. ${ }^{60}$ Squatters lived where no one else could afford to live, in some sense legitimizing the unaffordable price of real estate.

For decades after the Second World War, urban squatting offered a vivid 25 allegory for what it meant to resist state failures to provide housing and corporate incursions on real estate. Even while the sources of urban control over the city shifted from urban planning to neoliberal market investments in the city, squatters continued to adapt, targeting rich but empty neighborhoods like that of millionaire's row in London, where a ghost town of empty mansions signaled 30 that real estate had definitively been transformed from use value into a pure investment value.

The stakes of this encounter were plain to many observers. Squatter activists and journalists created their own universities, offering free classes on aspects of political economy to others, and documenting their experience in photography, 35 art and historical essays. Their work extended to a critique, not only of the

60 Anders Corr, No Trespassing!: Squatting, Rent Strikes, and Land Struggles Worldwide (South 
state's failure to provide housing, but also of the effects of gentrification on the 1 public sphere. By occupying neighborhoods that capital appreciation had put out of circulation, squatters dramatized how collectively-owned investments in infrastructure such as sidewalks, roads, sewers, train stations, and even housing itself had been effectively captured by market investors who themselves never 5 used these amenities.

In 2012, squatting was finally declared a criminal offense in Britain. At the same time, a new set of anti-rent movements was on the rise, taking the form of Occupy. Today, the forefront of urban intervention is not the squatters but the participatory activists who are heir to the legacy of Dudley Stamp and other 10 dreamers of public maps. Groups such as Public Lab and the g0v (pronounced "Gov-Zero") Movement in Taiwan form a "shadow government" of citizens collectively monitoring air and water quality, the availability of housing, and other aspects of public life. Reproduced through academic organs such as the Civic Media Lab at MIT, these movements are actively inserting the collection 15 and monitoring of urban data as part of what it means to actively resist state or corporate power in the city. Civic tech work, in this sense, is a response to neoliberalism, working to re-instill the ethos of democratic decision-making in public institutions even in an era when states themselves have been less experimental in terms of participation.

Mainly these groups have focused upon generating collective articulations of public needs and desire, for example in the form of public spaces, public transit, bike paths, or schools. Civic Tech targets urban government at a moment when cities and states are effectively outcompeted by private entities as a source of financial power for development, housing, and public space in the city. 25 Citizen initiatives to help the city's poorest citizens by planting urban gardens, for instance, which in the 1930s or 1960s might have been engineered by the state.

The irony is, of course, that in a neoliberal age the political will has rarely existed to channel money from private development to public infrastructure; 30 far from it, in 2017, the United States Congress voted to repeal Net Neutrality, thus taking the nation further away from a public infrastructure that would serve all populations equally. Nor has Civic Tech typically taken its mandate as the critique of private development or private capital, the actual site where decision-making about urban resources is typically located.

Public movements might be best served by setting out a mandate - a list of consumer demands - for companies to respond to, in much the same way as Taiwan used Polis to generate a citizen statement of needs that preceded and undergirded its negotiations with Uber. This form of citizen-generated statement opens up the possibility for further negotiations between an active participatory 40 
sphere and the world of private designers of infrastructure, where the state's role 1 might shift from expert designer and builder of infrastructure, to intermediary and negotiator between citizen forums and corporate builders? What sorts of demands might citizens lay down, were they to generate a mandate for private developers with respect to housing?

One of the strongest promises of the participatory movement is the possibility of issuing a broadcast call for data-collection in the name of self-enlightenment. The preceding sketch, the work of a single historian working in isolation from today's data-driven participation campaigns, is not sufficient to produce a portrait of the neoliberal revolution, the participatory revolution, and 10 the extent to which participatory urban planning has achieved a moral victory in governments, cities, and academic institutions whilst simultaneously losing access to the financial means of reproducing cities. As a result, this article will shift from a sketch of the last century of debate over government and the city to a proposed research agenda.

This research agenda is imagined in terms of the data collection that could be accumulated by contemporary participatory movements, with their crowdsourcing armies of data-literate curators of documents. A collaborative, international, multi-city analysis of the history of city finance will contribute to helping the urban activists of the future to understand the limits to their successes in 20 defending urban infrastructure, housing, and food security.

\section{An Agenda for Citizen Collection of Data}

The rise of "citizen science" and the decentralized collection of data puts social science in a new position where our best work might depend upon calling for public data-gathering and analysis, rather than working as private citizens

A working list of what the public needs in order to better understand the history of urban planning and the availability of funds for city development in a 30 neoliberal context:

- The amount invested by each city and federal government in all categories of urban improvement, including housing, infrastructure, and education, since 1965;

- An archive of public regulations of private developers, including building 35 codes, historical preservation codes, incentives to create housing, privatelyowned public spaces, etc. A timeline of regulations in each category, as well as events that demonstrate their success or failure, that would make the history of these negotiations transparent to the public; 
- The amount invested by private developers over the same time period; 1

- A comparison, in base numeric terms, of the wealth represented by public and private building;

- A comparison of rents paid to public and private entities during that time;

- Any caps on the appreciation of rent per year that apply to particular 5 neighborhoods of classes of houses;

- Any ceilings on rent that apply to particular neighborhoods of classes of houses;

- Any prohibitions against the eviction of tenants that apply to particular neighborhoods of classes of houses;

- Other forms of rent control that apply to certain neighborhoods and dwellings;

- A tally of public money invested into building housing, homeless shelters, etc., by that time, with a tally of space per head;

- A tally of private money invested into building housing, homeless shelters, 15 etc., by that time, with a tally of space per head.

Another research initiative might focus on the question of how much of the banking industry and public revenue is dedicated to making sure that developed-world currencies continue to out-compete those in the developing 20 world:

- The current cost of bailouts from state to remedy bubbles in financial markets, including the cost of government purchasing stock;

- The current cost of tax programs subsidizing mortgages in the upper tier ( $>$ \$500k/home) or building programs designed to create those homes.

A citizen-directed movement that wished to harness corporate expenditure in a neoliberal age for the purposes outlined by citizen movements would do well then to construct a retrospective history of how much expenditure has come to be beyond citizen reach. Armed with that knowledge, 30 citizen groups could theoretically put themselves in a position to issue constructive propositions for the future use of funds. Taiwan's experience negotiating with Uber on the basis of a citizen-designed vision for urban administration shows how citizen-directed platforms can be used to counter corporate spending by outlining basic restraints on market principles. Based 35 on the study of this data, scholars and citizens might, in the future, issue a call for the uses of infrastructure based on citizen platforms, and a citizen proposal for the revision, retraction, or extension of public regulations regarding building. 